\title{
The greenhouse index of sustainable development for metallurgical processes of production in aspect of green power
}

\author{
Vladimir Lisienko ${ }^{1}$, Valery Anufriev ${ }^{2}$, Dmitry $_{\text {Berg }}^{3}$, Yuri Chesnokov ${ }^{1}$, and Anna Lapteva ${ }^{1 \mathrm{a}}$ \\ ${ }^{1}$ Ural Federal University, Institute of radio electronics and information technologies, Department \\ Automatics, 620002, Yekaterinburg, Russia \\ ${ }^{2}$ Ural Federal University, Higher School of Economics and management, Department Economy \\ of production and power systems, 620002, Yekaterinburg, Russia \\ ${ }^{3}$ Ural office of the Russian Academy of Sciences "Institute of industrial ecology", 620002, \\ Yekaterinburg, Russia
}

\begin{abstract}
The accounting of greenhouse gases (GHG) according to plans of the Russian Federation becomes obligatory since 2016 for the enterprises with issue of GHG not less than 150 thousand tons of $\mathrm{CO} 2$, since 2017 - from 50 thousand tons of CO2. Introduction of a carbon tax ( 15 dollars/t of CO2) is planned. Voluntary inventory of GHG of the enterprises and territories which in the long term apply is carried out to be called clever. According to University of Cambridge (USA) about $45 \%$ depreciation of joint-stock portfolios in the world markets, the expected climate change connected with are expected. Parameter for an assessment of the clever city with the developed metallurgy and need of decrease in greenhouse emissions in the atmosphere - the indicator of a sustainable development considering emission of carbon dioxide, prime cost of steel and its power consumption is offered. Its values for tandems blast furnace (BF) + oxygen converter (OC), BF, Corex, Romelt, Midrex, Hyl-3 everyone with arc furnace (AF) are defined.
\end{abstract}

The modern "clever" cities are not only environmentally friendly cities, but also the cities in which it is developed industrial, including, metallurgical production. At the same time the problem of emission of the GHG exerting a great influence on an ecological situation is of great importance. The submitted report just is also devoted to the choice of technologies with the minimum emission of GHG.

The accounting of GHG according to plans of the Russian Federation becomes obligatory since 2016 for the enterprises with issue of GHG not less than 150 thousand tons of $\mathrm{CO} 2$, since 2017 from 50 thousand tons of $\mathrm{CO} 2$. Introduction of a carbon tax is planned, the preliminary cost of 1 ton of $\mathrm{CO} 2$ is designated in 15 dollars. Voluntary inventory of GHG of the enterprises and territories which in the long term can apply for recognition by clever is carried out. According to University of Cambridge (USA) about $45 \%$ depreciation of joint-stock portfolios in the world markets, the expected climate change connected with are expected.

${ }^{a}$ Corresponding author: annalapteva@mail.ru 
Green technologies and sustainable development is the principles at which development becomes steadier, and resources are used more rationally. They assume decrease in negative impact on environment - is the main line of green technologies. This development is "proceeding" ("self-sufficient"), that is such which doesn't contradict further existence of mankind and its development in the former direction. In this plan it is known that the emission of GHG which is directly connected with power component, can make negative impact on a condition of climate. To UrFU the break-through technique of the accounting of GHG so far on the example of the enterprises the supplementing a technique of Intergovernmental Panel on Climate Change (IPCC) is mastered [1]. It is based on use of indicators of physical and chemical processes and gave more exact results when calculating GHG at the level of units (AF, OC, etc.) and the subsequent decrease in issue of CO2 at energy efficiency increase. Further this technique can be adapted for color metallurgy and chemical industry. Such approach is very important for transformation to the clever cities industrial and monotowns, such as Nizhny Tagil, Magnitogorsk, Lipetsk, Cherepovets, etc.

This work is also devoted to a problem of emission of GHG - carbon dioxide - when functioning one of the most power-intensive branches of the industry - ferrous metallurgy. There is a problem of formalization of definition of green technologies. For these purposes index of sustainable development - the indicators allowing to judge a state or change of an economic, social or ecological variable serve.

The index of sustainable development determined by a formula is offered:

$$
K_{E}=\alpha_{1} \cdot y_{1}+\alpha_{2} \cdot y_{2}+\alpha_{3} \cdot y_{3}
$$

where $\alpha_{1}+\alpha_{2}+\alpha_{3}=1$ - weight coefficients; $y_{1}-$ relative through emission of carbon dioxide; $y_{2}$ - relative prime cost of the product received in some processes; $y_{3}$ - relative through power consumption of this product.

Relative through emission of carbon dioxide is defined as

$$
y_{1}=I_{i} / I_{\max }
$$

where $I_{i}$ - specific through emission of technological process or a carbon trace, $\mathrm{kg}$ on $\mathrm{t}$ of production; $I_{\max }=3000$ - the greatest possible through emission of carbon dioxide in the considered processes, $\mathrm{kg} / \mathrm{t}$ of production.

Relative prime cost of a product is determined by a formula

$$
y_{2}=P C_{I} / P C_{\max }
$$

where $P C_{I}-$ prime cost of a product in i process, ruble on $\mathrm{t}$ of product; $P C_{\max }=30,000-$ the maximum prime cost of a product, ruble on $t$ of product.

Relative through power consumption of a product is determined by a formula

$$
y_{3}=T F N_{i} / T F N_{\max }
$$

where $T F N_{i}$ - specific power consumption of a product in technological fuel numbers, $\mathrm{kg}$ of equivalent fuel on $\mathrm{t}$ of production; $T F N_{\max }=1,500 \mathrm{~kg}$ of equivalent fuel $/ \mathrm{t}$ of production the maximum power consumption of production.

The offered index of sustainable development characterizes processes from the following points of view: emissions of greenhouse gas, expenses of work and materials, consumption of energy resources. Such indicator can be used for an assessment of various processes. In this article it is applied to an assessment of processes of production of cast iron and steel. In these processes the main formed greenhouse gas is carbon dioxide as other emitted gases (methane, carbon oxide, hydrogen) are a part of the secondary energy 
resources which are used in metallurgical processes as fuel, burning down to carbon dioxide and water.

The following metallurgical conversions are allocated for which index of sustainable development are calculated: BF, Corex, Romelt, Midrex, Hyl-3, OC, AF [1-4]. In processes of BF, Corex, Romelt cast iron is melted. In processes of Midrex, Hyl-3 sponge iron is formed. Cast iron or sponge iron are loaded into OC or AF in which steel is melted. The following tandems of technologies are analysed: $\mathrm{BF}+\mathrm{OC} ; \mathrm{BF}+\mathrm{AF}$; Corex $+\mathrm{AF}$; Romelt + AF; Midrex + AF; Hyl-3 + AF. At the exit of all combinations of repartitions for comparability the same product - crude steel was accepted.

Prime cost of crude steel is taken from [5]. Product cost in Russia in the present is characterized by considerable instability.

The technique and formulas for calculation of through emission of carbon dioxide are given in works [6-10].

The technique and formulas for calculation of TFN are taken from [11-14]. Calculations are carried out with the following values of coefficients: $\alpha_{1}=0.3 ; \alpha_{2}=0.5$; $\alpha_{3}=0.2$. The priority is given to prime cost. Results of calculations of values of the index of sustainable development are given in table 1 .

Table 1. Ranging of processes on values of the index of sustainable development $\mathrm{K}_{\mathrm{E}}$.

\begin{tabular}{|c|c|c|c|c|c|c|c|}
\hline \multirow{2}{*}{$\begin{array}{c}\text { Designation } \\
\text { of a technological } \\
\text { chain }\end{array}$} & \multirow{2}{*}{$\begin{array}{c}\text { Index } \\
\mathrm{K}_{\mathrm{E}}\end{array}$} & \multirow{2}{*}{ 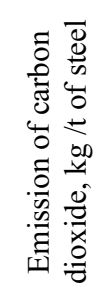 } & \multirow{2}{*}{ 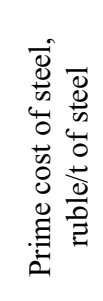 } & \multirow{2}{*}{ 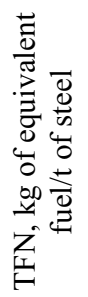 } & \multicolumn{3}{|c|}{ Priority on } \\
\hline & & & & & $\mathrm{K}_{\mathrm{E}}$ & TFN & $\begin{array}{l}\text { prime } \\
\text { cost }\end{array}$ \\
\hline AF on the scrap & 0.534 & 1,024 & 20,649 & 441 & 1 & 1 & 7 \\
\hline Hyl-3 + AF & 0.562 & 1,203 & 18,997 & 630 & 2 & 2 & 2 \\
\hline Midrex + AF & 0.577 & 1,258 & 19,376 & 639 & 3 & 5 & 3 \\
\hline $\mathrm{BF}+\mathrm{AF}$ & 0.602 & 1,434 & 20,123 & 634 & 4 & 4 & 6 \\
\hline Corex $+\mathrm{AF}$ & 0.703 & 1,904 & 16,380 & 632 & 5 & 3 & 1 \\
\hline Romelt $+\mathrm{AF}$ & 0.770 & 2,036 & 19,982 & 911 & 6 & 6 & 5 \\
\hline $\mathrm{BF}+\mathrm{OC}$ & 0.733 & 2,182 & 19,893 & 917 & 7 & 7 & 4 \\
\hline
\end{tabular}

In table 1 technological chains are located on increase in values of the index of sustainable development. As appears from calculations, the steel melted in AF from metal scrap has the minimum value of the index of sustainable development. As we see, AF on scrap, Hyl-3 $+\mathrm{AF}$, Midrex $+\mathrm{AF}$, tandem $\mathrm{BF}+\mathrm{AF}$ at prevalence of scrap in furnace charge of AF enters in the five of the most priority processes on this indicator.

Thus, as appears from table 1, on values of the index of sustainable development first place is won by the processes which aren't connected directly with production of cast iron. Further processes in which in a varying degree in initial furnace charge cast iron is used follow.

Results of calculations with the following values of coefficients: $\alpha_{1}=0.3 ; \alpha_{2}=0.2$; $\alpha_{3}=0.5$ are given in table 2 . The priority is given to through power consumption. 
Results of calculations with the following values of coefficients: $\alpha_{1}=0.5 ; \alpha_{2}=0.2$; $\alpha_{3}=0.3$ are given in table 3 . The priority is given to through emission of carbon dioxide.

Table 2. Ranging of processes on values of the index of sustainable development $\mathrm{K}_{\mathrm{E}}$ for values of coefficients $\alpha_{1}=0.3 ; \alpha_{2}=0.2 ; \alpha_{3}=0.5$.

\begin{tabular}{|c|c|c|}
\hline Designation of a technological chain & Index $\mathrm{K}_{\mathrm{E}}$ & Priority according to $\mathrm{K}_{\mathrm{E}}$ \\
\hline AF on the scrap & 0.460 & 2 \\
\hline Hyl-3 + AF & 0.562 & 4 \\
\hline Midrex + AF & 0.574 & 3 \\
\hline BF + AF & 0.562 & 5 \\
\hline Corex + AF & 0.721 & 6 \\
\hline Romelt + AF & 0.813 & 7 \\
\hline BF + OC & 0.809 & \\
\hline
\end{tabular}

Table 3. Ranging of processes on values of the index of sustainable development $\mathrm{K}_{\mathrm{E}}$ for values of coefficients $\alpha_{1}=0.5 ; \alpha_{2}=0.2 ; \alpha_{3}=0.3$.

\begin{tabular}{|c|c|c|}
\hline Designation of a technological chain & Index $\mathrm{K}_{\mathrm{E}}$ & Priority according to $\mathrm{K}_{\mathrm{E}}$ \\
\hline AF on the scrap & 0.440 & 1 \\
\hline Hyl-3 + AF & 0.516 & 3 \\
\hline Midrex $+\mathrm{AF}$ & 0.531 & 4 \\
\hline $\mathrm{BF}+\mathrm{AF}$ & 0.562 & 5 \\
\hline Corex $+\mathrm{AF}$ & 0.693 & 6 \\
\hline Romelt $+\mathrm{AF}$ & 0.766 & 7 \\
\hline $\mathrm{BF}+\mathrm{OC}$ & 0.771 & \\
\hline
\end{tabular}

\section{Conclusions}

Within green power for the industrial city with the developed metallurgy the index of sustainable development taking into account emissions of carbon dioxide, prime cost and power consumption of made steel is being devised. The technique of their definition is offered. Calculations for this technique revealed tandems of repartitions which are the most preferable from the point of view of emission of carbon dioxide and product cost.

The smallest values of these indicators are inherent in processes of production of steel in which cast iron isn't used.

The economic (cost) essence of power-ecological and power-greenhouse analyses consists in close interrelation of concepts of these analyses and of expenses of the user of nature on a payment for emissions by performing of technological processes.

Change of values of weight coefficients slightly change a picture on values of indexes of sustainable development. 
The recommended processes provide considerable decrease in greenhouse emissions within the industrial city and green power.

\section{References}

1. Yu.N. Chesnokov, V.G. Lisienko, A.V. Lapteva, Steel, 8, 74-77 (2011)

2. V.G. Voskoboynikov, V.A. Kudrin, A.M. Yakushev, General metallurgy (Moscow, 1998)

3. V.G. Voskoboynikov, V.A. Kudrin, A.M. Yakushev, General metallurgy: The textbook for higher education institutions (Moscow, 1985)

4. Yu.S. Yusfin, N.F. Pashkov, Metallurgy of iron: The textbook for higher education institutions (Moscow, 2007)

5. V.A. Romenets, Process Romelt (Moscow, 2005)

6. V.G. Lisienko, V.V. Krivorotov, D.B. Berg, Yu.N. Chesnokov, A.V. Lapteva, Bulletin UFU: "Series Economics", 6, 18-24 (2015)

7. V.G. Lisienko, Yu.N. Chesnokov, A.V. Lapteva, Metallurgist, 7, 40-45 (2011)

8. Yu.N. Chesnokov, V.G. Lisienko, A.V. Lapteva, Collection of scientific works of the AllRussian scientific and practical conference "Engineering Ecology", 50-54 (2011)

9. Yu.N. Chesnokov, V.G. Lisienko, A.V. Lapteva, Metallurgist, 12, 23-26 (2012)

10. V.G. Lisienko, Yu.N. Chesnokov, A.V. Lapteva, Metallurgist, 5, 18-24 (2015)

11. V.G. Lisienko, N.V. Solovyova, O.G. Trofimova, Alternative metallurgy: alloying problem, model estimates of efficiency (Moscow, 2007)

12. V.G. Lisienko, S.E. Rozin, Ya.M. Schelokov, News of higher education institutions. Ferrous metallurgy, 2, 108-112 (1987)

13. V.G. Lisienko, O.G. Druzhinina, V.A. Morozova, News of higher education institutions. Ferrous metallurgy, 9, 61-65 (1999)

14. V.G. Lisienko et al., News of higher education institutions. Ferrous metallurgy, 7, 6972 (1998) 